\title{
PLASTIC MONEY PERCEPTION FOR CUSTOMERS WITH REGARD TO INDIA SUSTAINABLE BANKING
}

\author{
Nagalakshmi $\mathbf{M}^{1}$, Dr.V.Andal ${ }^{2}$ \\ ${ }^{1}$ Research Scholar, Department of Commerce, Vels Institute of Science, Technology and Advanced Studies, Chennai, \\ Tamil Nadu \\ ${ }^{2}$ Associate Professor and Research Supervisor, Department of Commerce, Vels Institute of Science, Technology and \\ Advanced Studies, Chennai, Tamil Nadu
}

\begin{abstract}
It is critical to integrate technology in order to create a sustainable financial environment. Modern banks have propelled plastic money as part of this. Customers in India are impressive in their perceptions about plastic money. This is what aspects affect the Bank's good opinion of plastic money but whether or not they face issues. One of the key emphasis of this research is to analyse the perceptions of customers regarding plastic money. Approximately 200 replies to the study were collected. The test of hypotheses was carried out using a quantitative research design. The survey results showed that customer attitude to plastic cash has had beneficial effects on usage and financial rewards, convenience considerations and psychological aspects. In addition, the respondents have highlighted certain concerns as clients.
\end{abstract}

Keywords: plastic money, perception of clients, sustainability, bank, India

\section{INTRODUCTION}

We are increasingly depending on new developments to make our transactions more efficient and productive. The continued and rapid development of innovation has resulted in significant changes in our routine day-to-day lives (Panagiotis et al., 2018). Plastic money is a modern way of payment that is significantly altering the traditional concept of monetary payment. Today's financial competition has compelled banks to reassess their efforts to find low-cost replacement products for banking activities.

Plastic money is beneficial to banks since it increases production and allows them to provide better services to their customers (Kaur \& Sharma, 2017). Every financial institution is utilising this method, obliging all of their clients to take advantage of these systems on the grounds of simplicity process, however an unanticipated money connected age to the bank (Odusina \& Ayokunle Olumide, 2014). Customers today cannot conduct banking transactions without the use of a plastic card. Plastic money eliminates the need to carry currency and lessens the risk of theft. Banks have recently begun to offer several sorts of plastic money cards to meet the needs of their customers, such as a debit card, credit card, visa card, and master card. Credit cards relieve clients of the hassle of carrying cash and provide security. It is the convenience of increased credit without the need for custom (Sunayna Khurana \& Satendra Pal Singh, 2011). Banks now issue plastic cards to their customers, which has altered the banking system in India.

The growth of the plastic money industry was quite visible as people became more dependant on technology, and the plastic money business is the best consequence of technical innovation in the banking sector (Sumi \& Safiullah, 2014). The goal of our research is to examine customers' attitudes on plastic money in India. We have particular goals such as identifying perceived benefits of plastic money to customers, identifying perceived disadvantages to customers, and scrutinising the psychological and attitudinal variables of customers for plastic money usage.

\section{RESEARCH OBJECTIVES}

The overall goal of this survey is to determine how consumers feel about plastic money in the broadest sense. The precise goal is to accomplish the following:

- $\quad$ Discover perceived benefits for customers of plastic money

- $\quad$ identify perceived customer inconvenience of plastic money

\section{IMPLICATIONS OF RESEARCH}

Only a handful of papers have been located that detail the use of plastic money as a green banking alternative in India. Additionally, client sentiments about the use of plastic money in developing countries have not yet been researched

thoroughly." 


\title{
International Advanced Research Journal in Science, Engineering and Technology
}

\author{
Vol. 8, Issue 8, August 2021
}

DOI: 10.17148/IARJSET.2021.8829

This study will aid both banks and their clients in learning more about the impact of new technology on sustainable banking. At the same time, the findings of this study will help the financial institutions to evaluate and rectify the perceived weaknesses of present electronic trading devices by examining their perceived drawbacks.

\section{LITERATURE REVIEW}

As regards currency, the exchange and payment procedures demand money. Because of recent advances, the conventional form of money - coins - has evolved into paper money and money is currently available as plastic money in a shapeless state in the past decade (Bishty et. al., 2015).In today's banking business, modern technology-based processes have superseded conventional approaches based on technology. The utilisation of plastic card technology was linked to consumer credit demand (Hugar \& Basavaraj, 2014). Functional and technological conditions were found in the banking industry as a way to quantify consumer satisfaction (Gronroos, 1984).

For your transactions, most clients appreciate using the debit card instead of the credit card. Customers generally appreciate using debit cards for the purchase of appeals, power bills, telephone charges etc. Many customers believe that debit card is more conducive than credit card, since debit cards allow more spending control, good cash back policies and robust security. In addition, the majority of plastic money users utilise this for online transactions as they feel safe online transactions but they shun it totally when using it for other financial transactions (Bishty et. al., 2015).

\section{RESEARCH METHODOLOGY}

Approach of sampling: a convenient random sample method for picking the respondents has been selected. For the study, people using plastic money were considered. Contacts based on their internet activity were contacted. Method of data gathering: A systematic survey for data collecting has been developed. About 500 questionnaires were given and 200 with the answer rate of 40 percent returned. Analysis of all surveys. Analytical method: The purpose of this study is to assess the attitudes of customers about one of sustainable banking technological adoptions with relation to plastic money. This study is compatible with the quantitative research design. KMO Factor analyses and descriptive statistics for analysis of the study framework have been selected as statistical analysing methods.

\subsection{Demographic data of the respondents}

\section{DATA ANALYSIS AND INTERPRETATION}

Different demographic respondents participated to validate the accumulation of information. There were 39.7 percent females and 60.3 percent males among the 200 responses. Youth (age 18-25, 26-35) were the dominant responses and only 10 percent of them were seniors. This shows that the utilisation of plastic money by young people in India is extensive. The fact that persons from lower middle class backgrounds are more likely to use plastic money is another crucial indicator of this trend. In the study, there were around 58 percent of respondents who had a monthly income of less than Rs. 25,000.

Figure 2 reveals that the most widely used plastic card between respondents ( 44.50 percent) is a debit card, followed by an ATM card, a credit card, a visa card, and a master card. Plastic use and users in India are quickly expanding as individuals wouldn't want to handle cash in their pockets for their own protection and security.

\section{Chart Based On Income Level}

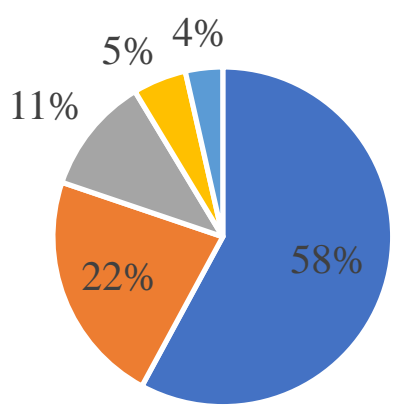

$$
\begin{gathered}
\text { Below } \\
25000 \\
-25000- \\
40000 \\
41000- \\
55000 \\
55000- \\
70000 \\
\text { Above } \\
70000
\end{gathered}
$$

Fig.1. Respondents' income levels 


\section{International Advanced Research Journal in Science, Engineering and Technology}

Vol. 8, Issue 8, August 2021

DOI: 10.17148/IARJSET.2021.8829

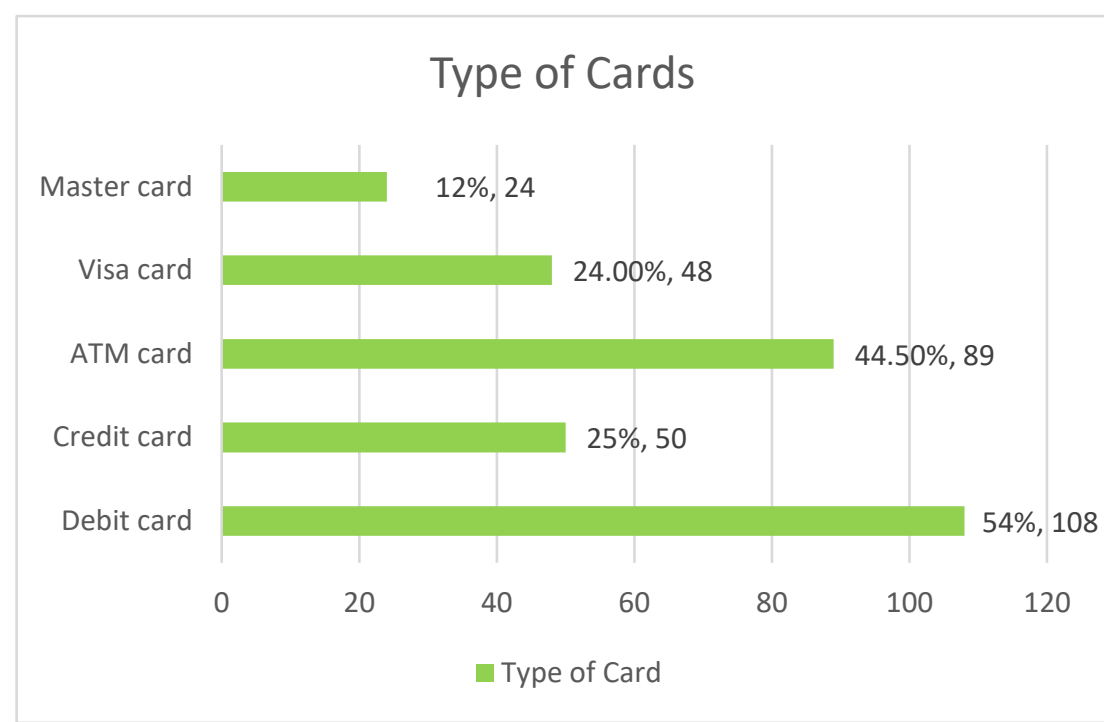

Fig. 2. Respondents Card Types

\subsection{Factor analysis}

Using this confirmatory factor analysis, we can validate our assumptions about how these dimensions were constructed and the cohesion of the items that went into this construction. Analysis of the factor would now validate our proposal with little action. Analysis of the factor type R was the evaluation method applied. The findings of the analysis showed that the factor analysis was satisfactory overall and the Kaiser-Meyer-Olkin sample adequacy measurement was employed to monitor excessive correlations with a value equal to 0.718 (preferred KMO value should be greater than 0.5 ) in the Table 1 . This indicates that modest correlations exist between variables.

Table.1. KMO \& Bartlett's Test

\begin{tabular}{|c|c|}
\hline Kaiser-Meyer-Olkin Measure of Sampling Adequacy & $\mathbf{0 . 7 1 8}$ \\
\hline Bartlett's Test of Sphericity Approx. Chi-Square & $\mathbf{3 9 0 . 6 9 7}$ \\
\hline Df & $\mathbf{3 7}$ \\
\hline P-Value & $\mathbf{0 . 0 0 0}$ \\
\hline
\end{tabular}

\subsection{Descriptive statistics}

Issues with plastic money include: The figure depicts the means and standard deviations for all of the dimensions combined. In Likert scale measurement, all aspects are taken into consideration ( 1 is strongly agree and 5 is strongly disagree). According to the findings, the perceived component with the highest mean value was fake cash at an ATM $($ mean $=2.55)$, while the perceived dimension with the lowest mean score was a relatively high service fee $($ mean $=2.20)$. (table-2). According to the findings, fake cash at ATMs and limited global access are extremely difficult for the respondents, whereas all other characteristics are considered as fairly relevant by the sample. There is disagreement among respondents about the lack of money at ATMs, uncontrollable overspending, and limited global access. The standard deviation values for these dimensions are larger than those for other dimensions.

Table.2. Descriptive statistics of issues with plastic money

\begin{tabular}{|c|c|c|}
\hline Plastic Money Issues & Mean & S.D \\
\hline Few Sellers & 2.37 & .839 \\
\hline Limited global access & $\mathbf{2 . 5 2}$ & $\mathbf{1 . 0 0 8}$ \\
\hline Magnetic strap that has been damaged & 2.37 & .887 \\
\hline Relatively high service fee & $\mathbf{2 . 2 0}$ & .916 \\
\hline The Number of frauds is increasing. & 2.38 & .842 \\
\hline Complications due to technology & 2.25 & .945 \\
\hline Fake cash at the ATM & $\mathbf{2 . 5 5}$ & .998 \\
\hline Lack of money at ATM's & 2.29 & $\mathbf{1 . 0 5 3}$ \\
\hline Uncontrollable overspending & 2.26 & $\mathbf{1 . 0 1 1}$ \\
\hline
\end{tabular}




\section{International Advanced Research Journal in Science, Engineering and Technology}

Vol. 8, Issue 8, August 2021

\section{DOI: 10.17148/IARJSET.2021.8829}

\section{FINDING AND CONCLUSIONS}

It is found from demographic statistics that much of the sample comes from the young and the lower middle classes. Most of the participants have ATM plastic and debit cards. In order to assess client views, the perceived advantages found within the research framework were examined. Certain difficulties have been observed with plastic cards. Most of the results showed that the plastic cards were of disadvantage. Descriptive statistics show that the respondents were severely challenged by fake cash in the ATM and limited global access

Present era, plastic money transactions are easier as paper money is not necessary. The use of plastic money is expanding every day for foreign purchases. In India, the spread of plastic money is caused by the middle class and the benefits of plastic cards are identical to that seen by everybody. Sustainable banking is a beneficial approach to such technological development. People don't have to consider about the money, but just put a plastic chip in a wallet. However, shopping advantages cannot affect buyers' optimistic vision. Banks should therefore take appropriate steps to make it easier for clients to shop using plastic money. In the use of the card, other issues were also found. Banks should also observe and take initiatives to ensure effective and sustainable banking in India to deal with the challenges faced by clients.

\section{REFERENCES}

1. Deviranjitha, S., \& S. Thamilarasan.(2014)."A Study on usage and satisfaction of credit cards by customers in Krishnagiri district."International Journal of Business and Administration Research Review", 160.

2. Hasan, S. A., Subhani, M. I., \& Osman, M. (2011). plastic money/credit cards charisma for now and then (A thin line between easy money and risky money).

3. Manivannan, P. (2013). Plastic money a way for cash less payment System.Global Research Analysis,2, 10-12. https://doi.org/10.15373/22778160/January2013/84

4. Ramasamy, S. R., Guru, B. K., Nair, M., \& Vaithilingam, S. (2006). Development of E-money in Malaysia. InNational Statistics Conference, Putrajaya International Convention Centre, Putrajaya, Malaysia.

5. Sudhakar, G. (2014). Plastic Money: The Rise of E-Money.A Monthly Double-Blind Peer Reviewed Refereed Open Access International e-Journal

6. Anderson, W. T. (1972). Convenience orientation and consumption behavior.Journal of Retailing,48(3), 49.

7. Berry, L. L., Seiders, K., \& Grewal, D. (2002). Understanding service convenience.Journal of marketing,66(3), 117.https://doi.org/10.1509/jmkg.66.3.1.18505

8. Kelley, E. J. (1958). The importance of convenience in consumer purchasing.Journal of Marketing,23(1), 3238.https://doi.org/10.1177/002224295802300105

9. Vijayalakshmi S; Jahnavy S.. "A Comparative Study on Financial Performance of banking sectors". International Research Journal on Advanced Science Hub, 3, Special Issue 6S, 2021, 42-47.

10. Naga Siva Rama Murthy V. "Micro controller based Power Factor Correction". International Research Journal on Advanced Science Hub, 2, Special Issue ICIES 9S, 2020, 108-115. doi: 10.47392/irjash.2020.170

11. Sumi, F. R., \& Safiullah, A. B. (2014). Problems and Prospects of Plastic Money in Bangladesh.IOSR Journal of Business \& Management, 16 (12), 31-38.https://doi.org/10.9790/487X-161223138

12. Hugar, B. S., \& Basavaraj, C. S. (2014). A Study on Usage Pattern ofCredit Cards in Gulbarga City.Asian Journal of Research in Banking and Finance,4(11), 181-187.https://doi.org/10.5958/2249-7323.2014.01446.1

13. Bisht, A., Nair, P., Dubey, R., \& Hajela, T. (2015). Analysis of the use of plastic money: A boon or a bane.SIMS Journal of Management Research, 1 .

14. Childers, T. L., Carr, C. L., Peck, J., \& Carson, S. (2001). Hedonic and utilitarian motivations for online retail shopping behavior.Journal of retailing,77(4), 511-535.https://doi.org/10.1016/S0022-4359(01)00056-2

15. Coldwell, J. (2001). Characteristics of a good customer satisfaction survey.Customer Relationship Management, 193-199.

16. Goossens, C. (2000). Tourism information and pleasure motivation.Annals of tourism research,27(2), 301321.https://doi.org/10.1016/S0160-7383(99)00067-5

17. Khurana, S., \& Singh, S. P. (2011). An analytical study of customer's preferences and satisfaction in credit card industry.The IUP Journal of Bank Management,10(1), 71-87. 